\title{
Career Aspirations and Factors of Career Developments among Women in the Technical Field
}

\section{Zaliza Hanapi, Muhamad Shazielan Sharif, Ridzwan Che'Rus, Suriani Mohamed, Tee Tze Kiong, Abu Bakar Mamat}

To Link this Article: http://dx.doi.org/10.6007/IJARBSS/v9-i7/6802

DOI:10.6007/IJARBSS/v9-i7/6802

Received: 02 May 2019, Revised: 17 June 2019, Accepted: 30 June 2019

Published Online: 07 July 2019

In-Text Citation: (Hanapi et al., 2019)

To Cite this Article: Hanapi, Z., Sharif, M. S., Che'Rus, R., Mohamed, S., Kiong, T. T., \& Mamat, A. B. (2019). Career Aspirations and Factors of Career Developments among Women in the Technical Field. International Journal of Academic Research in Business and Social Sciences, 9(7), 1437-1442.

\section{Copyright: (C) 2019 The Author(s)}

Published by Human Resource Management Academic Research Society (www.hrmars.com)

This article is published under the Creative Commons Attribution (CC BY 4.0) license. Anyone may reproduce, distribute, translate and create derivative works of this article (for both commercial and non-commercial purposes), subject to full attribution to the original publication and authors. The full terms of this license may be seen at: http://creativecommons.org/licences/by/4.0/legalcode

Vol. 9, No. 7, 2019, Pg. 1437 - 1442

Full Terms \& Conditions of access and use can be found at http://hrmars.com/index.php/pages/detail/publication-ethics 


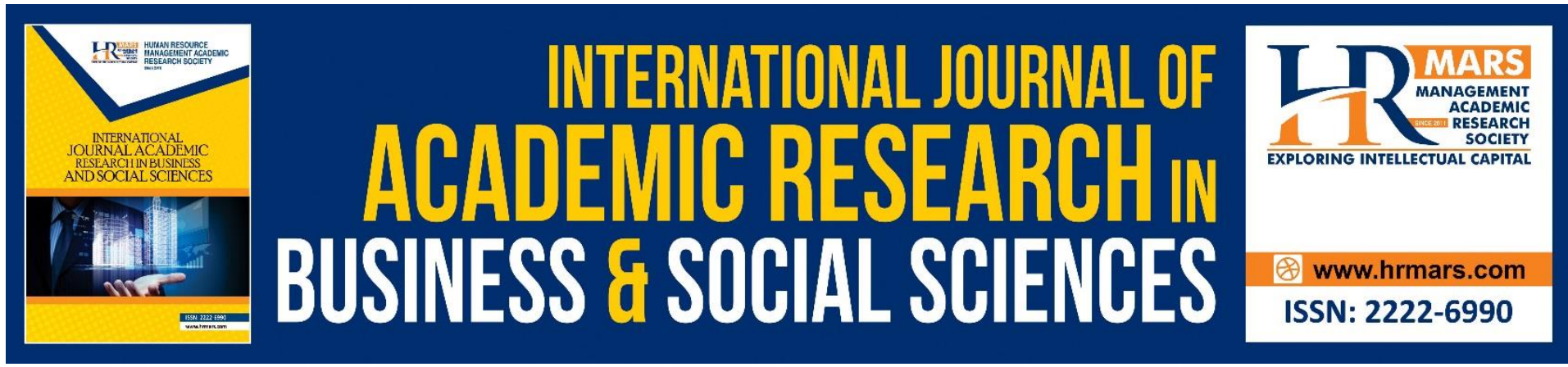

\title{
Career Aspirations and Factors of Career Developments among Women in the Technical Field
}

\author{
Zaliza Hanapi ${ }^{1}$, Muhamad Shazielan Sharif ${ }^{1}$, Ridzwan \\ Che'Rus' ${ }^{1}$, Suriani Mohamed ${ }^{1}$, Tee Tze Kiong², Abu Bakar \\ Mamat $^{1}$ \\ Faculty of Technical and Vocational Education, Universiti Pendidikan Sultan Idris, \\ 35900 Tanjong Malim, Perak, Malaysia ${ }^{1}$, Faculty of Technical and Vocational Education \\ Universiti Tun Hussein Onn Malaysia, Parit Raja, 86400 Batu Pahat, Johor, Malaysia ${ }^{2}$
}

\begin{abstract}
Nowadays, female students' participation in higher education institutions is more than male students with a 60:40 ratio and among this number of student enrollment, the number of female students choosing the technical field is also increased. However, the number of female students that managed to secure a job as a professional engineer has yet to be proud of. Hence, this study is conducted to examine thoroughly the aspirations and factors that influenced the development of women's career aspiration in the technical field, especially in the manufacturing sector. The respondents of this study consisted of 76 women that came from various fields of work. The findings show that career aspirations among women in the technical field are high and that the company's support, job security, and job performance indicates a significant factor which affects the development of women's career aspiration in the technical field. The results of this study will have an impact on the knowledge and provided more information for other researchers regarding women's career aspiration in the technical field that assists their career development.
\end{abstract}

Keywords: Career, Aspirations, Career Development, Women, Technical Field.

\section{Introduction}

Career aspirations are one of the aspects that affect the development and progression of an individual in their career or life. In today's world, with or without their higher education qualification, women also play an important role in helping to strengthen their family economy. However, as stated by Fatma and Bhati (2005) in their study of the key determinants of women's decision to join the labor market, the higher the level of education, the higher the tendency for women to join the labor market.

According to the latest statistics from the Department of Statistics Malaysia (2016), female labor force participation rate is $54.1 \%$, which is significantly different compared to the $80.6 \%$ male labor force participation. Due to the low labor force participation rates among 
women, it also caused the unemployment rates among women rose from $3.2 \%$ in 2014 to $3.4 \%$ in 2015. As stated by Jorah (2012), based on statistical reports in 2012, it shows that $67.1 \%$ of women are not joining the job sectors and the reason behind that is often related to family issues or to continue their studies. Nevertheless, the key reason identified is due to the employer's factors in which they do not understand the importance of women's contribution to the organization and its benefits to the company.

As claimed by Jorah (2012), salary, promotion and job performance should be based on a measurable, clearer, and more realistic factor. Hence, this study is conducted to examine thoroughly and with more details regarding career aspirations that women have towards their job and factors that influenced the development of women's career in the technical field, especially manufacturing sector.

The purpose and objective of this study conducted are to:

a) Explore career aspirations among women towards their chosen field of work

b) Explore the factors that influenced the development of women's career aspirations towards their job in the technical field.

\section{Literature Review}

Before this, women are better known as a housewife only. However, this view started to change in parallel with country development, as today's women have become one of the major contributors in achieving the status of a developed country. Based on the theory of human capital proposed by Becker (1975), educational and training institutions such as schools, universities, computer classes, and health education is considered as capital that can help enhance oneself. Education and training are process of learning that is structured to change the attitudes, enhance the knowledge and skills of an individual in order to have high self-esteem or career.

For developed countries that are investing in education, health, and training, in the long run, it will help to strengthen the economic structure and improve the living standard of their communities. The contribution of women, whether as a paid employee, wives or mothers are very important. In the Ninth Malaysia Plan (9MP), female employment has shown an increase in the numbers, especially in the manufacturing sector such as textiles and electronics. Tapsir and Noor (2005) in their study show that the development of women in the engineering field in Malaysia is low, but this situation also occurred in the developed countries where the number of female engineers is still significantly lower than that of men in this field.

In addition, according to the Human Development Report (2013), despite the numerous initiatives being given, the number of Malaysian women working in the formal labor remained low in spite of the fact that women were highly educated. In reference to a report released by the United Nations Development Program, women's participation in the workforce is low and adding to that there is wage discrimination between the sexes which impacts Malaysia's growth and the strive to liberate low-income households from the shackles of poverty. Therefore, to encourage more women in the workforce, certain changes need to be made. Changes such as the employment-related policies or regulations and 
employers' trust in female workers are necessary so that talented women can be given opportunities in tandem with male manpower.

\section{Research Methodology}

This study is a survey study using a quantitative study approach. The respondents for this study consisted of 76 women working in the manufacturing sector, which comprising various types of job titles such as engineers, supervisors, and technicians. The location for this study covers companies and factories involved in the manufacturing sector in Peninsular Malaysia (State of Penang, Selangor, Johor and Pahang which differ by zone).

\section{Findings}

\section{Demographic}

The respondents of this study consisted of 76 women working in the technical fields, especially in the manufacturing sector. The majority of the respondents has a Bachelor's Degree. The respondents involved also consisted of 42 (55.3\%) women who have 1-3 children, $18(23.7 \%)$ women have no children, and 16 (21.1\%) women have 4-6 children. Moreover, the majority of the respondents involved in this study works as an engineer with a total of 32 $(42.1 \%)$ respondents, while $26(34.2 \%)$ respondents work as supervisors, and only 18 (23.7\%) respondent work as technicians.

\section{The Findings of this Study are based on the Constructed Objective, which are}

\section{a) Career aspirations among women towards their chosen field of work}

Women's career aspirations in this study included three aspects which are leadership aspirations, achievement-aspiration, and educational aspirations. The findings show that the mean score of female career aspirations in the technical field is 4.34 (SP:0.39). The results also show that women have a higher level of achievement-aspiration based on the highest recorded mean score which is 4.56 (SP:0.48) compared to the educational aspirations and leadership aspiration with the total mean score of $4.34(0.48)$ and $4.07(0.80)$ respectively.

\section{b) The factors that influenced the development of women's career aspirations towards their job in the technical field.}

The factors involved in this study that affect the development of women's career aspirations towards their job in the technical field are the opportunity for the career development, the support from the company or the organization, job security, and job performance. From the results obtained, the mean score recorded for the career development opportunity factor is 3.91 (0.49), the mean score for the company support factor is $3.9(0.47)$, the mean score for the job security factor is 4.0 (0.53), and the mean score for the job performance factor is 4.14 (0.46). Based on the Pearson's Correlation Coefficient analysis, it was found that the company support factor recorded the value of $r: 0.254$ and $p \leq 0.027$ while job security factor recorded the value of $r: 0.245, p \leq 0.033$ and work performance factor recorded the value of $r: 0.426$ and $p \leq 0.00$ which has a significant and moderate correlation. This correlation affects the development of women's career aspirations in the technical field. 
The Correlation Relationships are as Shown in Table 1 below.

\begin{tabular}{|l|l|c|}
\hline \multicolumn{2}{|c|}{ Career Development Factors } & Women Career Aspiration \\
\hline \multirow{2}{*}{$\begin{array}{l}\text { The opportunities for career } \\
\text { development }\end{array}$} & Pearson Correlation & 0.146 \\
\cline { 2 - 3 } The company support & Sig. (2-tailed) & 0.207 \\
\hline \multirow{2}{*}{ Job security } & Pearson Correlation & 0.254 \\
\cline { 2 - 3 } & Sig. (2-tailed) & 0.027 \\
\hline \multirow{2}{*}{ Job performance } & Pearson Correlation & 0.245 \\
\cline { 2 - 3 } & Sig. (2-tailed) & 0.033 \\
\hline & Pearson Correlation & 0.426 \\
\cline { 2 - 3 } & Sig. (2-tailed) & 0.000 \\
\hline
\end{tabular}

Table 1: Correlation Test Analysis.

\section{Discussions and Conclusion}

Overall, the findings show that women have high career aspirations towards their job that they are involved in and that the company support, job security, and job performance were the significant factors that influenced the development of women's career aspirations in the technical fields. In today's world, women also play an important role in helping to strengthen their family economy with or without their higher education qualification.

According to Rahamah (2014); Yin, Yusof, Lok, \& Zakariya, (2018); Desfitrina, (2018), deeprooted view of traditional society, even in this era of modernization as such women only suitable in managing their household chores and the negative mindset of employers who see women that are juggling between their career and marriage will often take the leaves should be changed. This is because every human being possesses their own talent and abilities so as a woman. Women also have their own distinctive talent, and they should be given the same opportunity as men to succeed in the highest part of the job. Generally, the contribution of a woman is very important in life either as a paid employee or as a wife and a mother. Therefore, to encourage more women in the workforce, certain changes need to be made. Changes such as the employment-related policies or regulations and employers' trust in female workers are necessary so that talented women can be given opportunities in tandem with male manpower.

\section{Acknowledgement}

This research is under the University Research Grant (Project Code: 2017-0210-106-01), Research Center of Management and Innovation, Sultan Idris Education University.

\section{Corresponding Author}

Zaliza Hanapi, Faculty of Technical and Vocational Education, Sultan Idris Education University, Perak, Malaysia. Email: zaliza.hanapi@ftv.upsi.edu.my

\section{References}

Becker, G. S. (1975). Human capital: a theoretical and empirical analysis, with special reference to education. (Ed. ke-2). Chicago: The University of Chicago Press. 
Borland, J. (1999). Job security in Australia. Journal of Economic Perspective, 14(3), 115-136.

Desfitrina. (2018). The Influence, Gender, Life on Development Planning in Indonesia, International Journal of Academic Research in Accounting, Finance and Management Sciences 8 (3): 255-264.

Fatma, G. L., \& Eyza, B. (2005). Determinants of female labour force participation. A study of North Cyprus. Review of Social Economic and Business Studies, 5(6), 209-226.

Jorah, R. (2012). Women's Workers' Crash, Online Ministry of Family and Community Development Online News .The Women's Action Plan.

O'Neil, D. A. \& Bilimoria, D (2005). Women's career development phases: Idealism, endurance, and reinvention. Career Development International, 10(3), 168-189.

Osipow, S. H. (2012). Career Development. Encyclopedia of Human Behavior, 430-433.

Rahamah, N. A. B. (2014). The division of work by gender. Publisher: National University of Malaysia, Bangi.

Schwartz, D. B. (2004).The impact of work family policies on women's career development, Boon or Bust? Women in Management Review, 11, 5-19.

Social Statistics Bulletin Malaysia. (2001). Statistics Department, Government of Malaysia, p. $158-161$.

Tapsir, S. H. \& Noor, M. N. (2005). Women engineers in Malaysia. JURUTERA, http://dspace.unimap.edu.my/dspace/bitstream/123456789/13814/1/Women\%20E ngineers\%20in\%20Malay sia.pdf.

Umar, A. (2014). Effect of Wages, Work Motivation and Job Satisfaction on Workers' performance in Manufacturing Industry in Makassar City. European Journal of Business and Management, 6(5), 85-96. ISSN:2222-1905. 